\title{
Tourism constituents and tourism marketing in Oman ( Dhofar Governorate as a Model )
}

\section{Issa Taman Al amri - Dr. Abdelkader Sbai - Dr. Khadija Ben rabia}

Univercity Mohamed $1{ }^{\text {st }}$ Departement of Geography

Research Team "Geomatics and Territorial Management" 


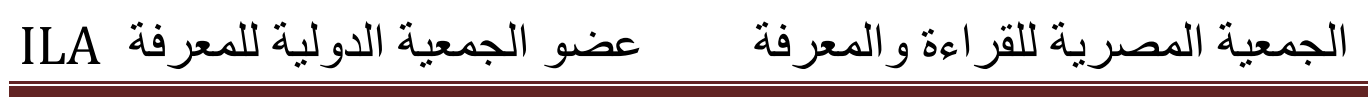




\section{الجمعية المصرية للقر اعة والمعرفة عضو الجمعية الدولية للمعرفة ILA}

Summary:Tourism in developing countries is seen as an important means of rapid investment, especially as there is a significant shift in tourism routes towards developing countries that have competed with developed countries in tourist attractions.

The Sultanate of Oman is characterized by a variety of tourist attractions, making it ranked first in the Arabian Gulf, where the natural components of Dhofar province play a large role in the development of tourism through the exploitation of these elements and configured as a tourist product that attracts large numbers of tourists to promote and recreation and exercise hobbies and enjoy the unique climate for the province, which affects the tourism development of different types of tourism activities throughout the year, where the Omani Ministry of Tourism is engaged in organizing entertainment events throughout the year for the tourists and pilot the internal tourism movement.

Based on the field data and the study of the various factors affecting tourism in the Sultanate of Oman - Dhofar Governorate model, analysis of its impact on the Omani product and how to market it locally, nationally and internationally.

Keywords: Tourism - Qualifications - Development - Marketing - Dhofar, Sultanate of Oman. 


\section{الجمعية المصرية للقر اعة و المعرفة عضو الجمعية الدولية للمعرفة ILA}

\section{المقومات السياحية والتسويق السياحي بسلطنة عمان

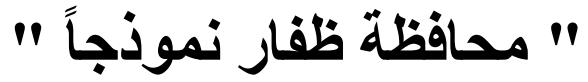 \\ عيسى تمان العمري - د. عبد القادر السباعي - د. خديجة بن ربيعة

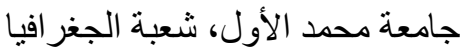 \\ فريق البحث: الجيوماتية و تدبير التراب الجنراب \\ edoorissa@hotmail.com}

ملخص: أصبح ينظر للسياحة في الدول النامية على أنها وسيلة هامة من وسائل الاستثمار السريع، خاصة التها أن هناك تحول كبير في المسار ات السياحية نحو الدول النامية الني أخذت تنافس الدول المتقدمة في الجذب التبات النياحي.

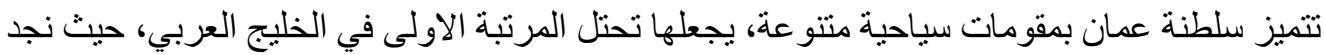

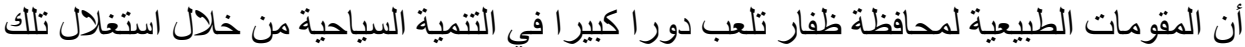

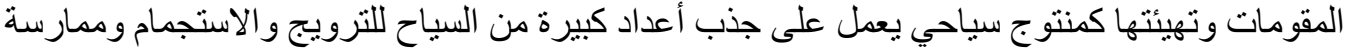

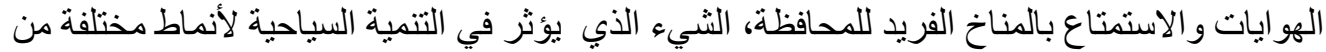

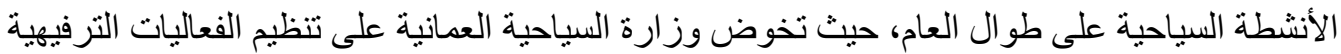

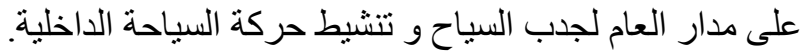

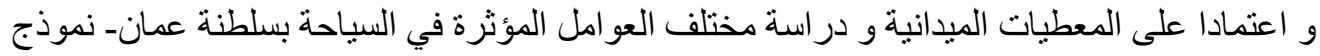

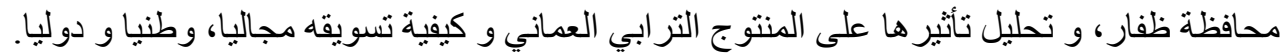

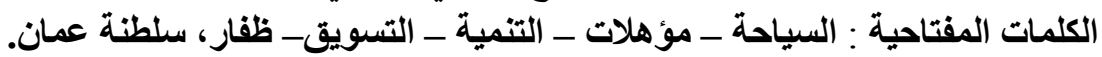

\section{Introduction}

The achievement of tourism development requires the concerted efforts of various specialists and stakeholders, which will lead in one way or another to the development of the tourism movement, which means uniting efforts to study tourism and identify the various problems, and their causes and how to find appropriate solutions to these problems, in a manner that accommodates the possibilities and elements And tourist attractions.

The tourist qualifications of Dhofar Governorate, represented by the beauty of nature, climate diversity, ease and diversity of customs and traditions, and easy access to tourist sites, play a crucial role in bringing a large number of tourists to ensure economic, social and environmental development by providing infrastructure, Environment, and will not achieve this goal as required only 


\section{الجمعية المصرية للقر اعة والمعرفة عضو الجمعية الدولية للمعرفة}

overcome the various problems that stand in the face of tourism development in the province and find appropriate solutions to them.

\section{The environmental elements of tourism development in Dhofar}

The natural components of the geographical location, climate and ecosystem of Dhofar Governorate are the main attractions of the province. The availability of natural elements is a key factor in tourism. If Lew (2008) divided natural attractions into: But the geographical location that is the container that contains all these divisions and affects, and the factors of proximity and geographical dimension of the countries exporting tourism has a clear impact on the volume of tourism traffic negatively and positively as will become clear, hence the importance of studying the geographical location in the Natural ingredients ${ }^{1}$ (Map 1).

\section{Map 1: Location of Dhofar}
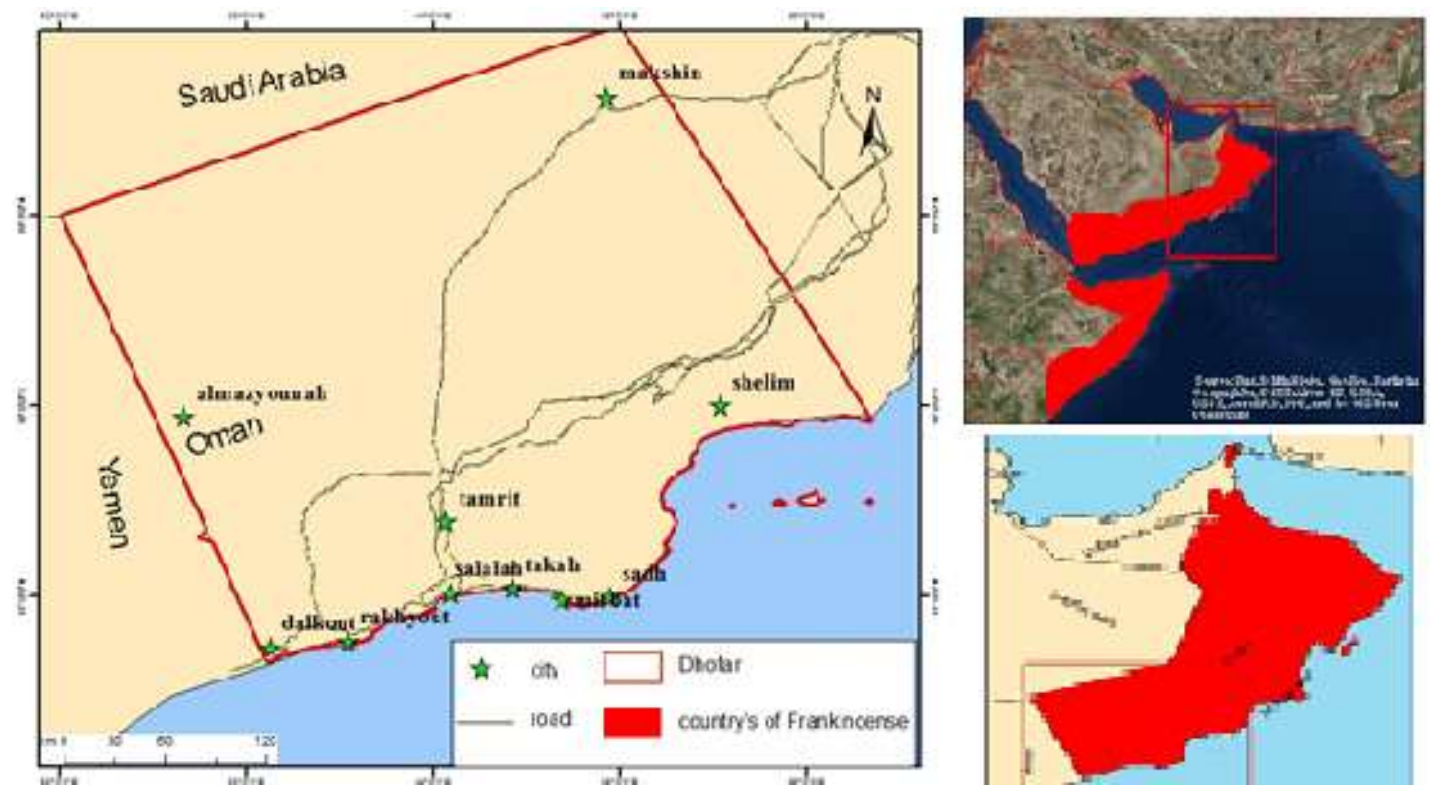

1 - Lew Alan \& al (2008): World Geography of Travel and Tourism: A Regional Approach, p:33. 
$\therefore$ Water resources as a basis for tourism activity 1.1

Dhofar has more than 208 eyes, most of which are permanent runoffs, and the most

.important elements of Al-Jarajah are Ain Rizat, Ayn Tobruk and Ein Atom

Map 2: The most important water springs in Dhofar

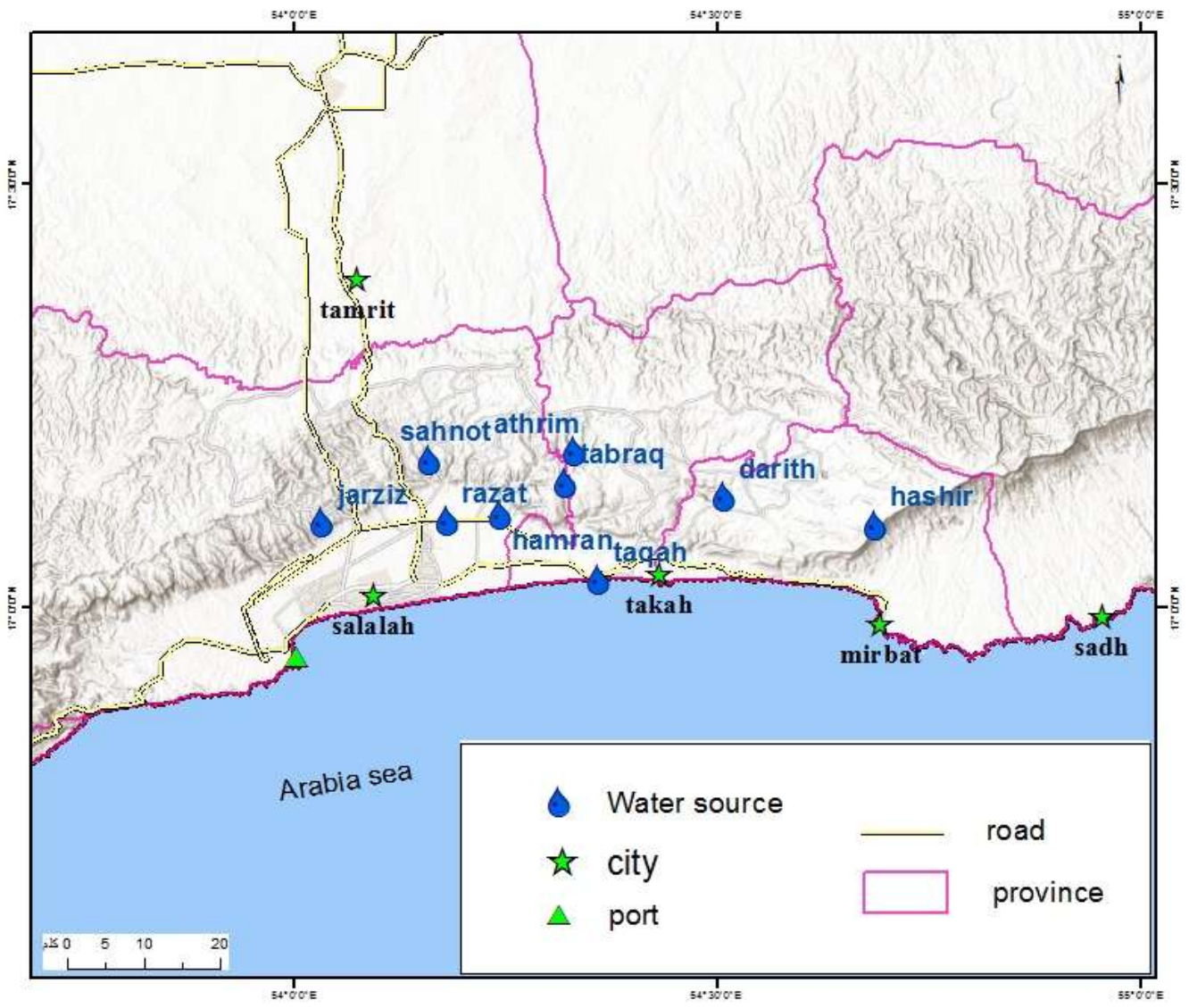

Source: Data of the Planning Committee for Environment and Development in Dhofar, without history, Khairan and Springs in Dhofar

Ain Rizat (picture 1), which is about $19 \mathrm{~km}$ from the city of Salalah, is one of the most important and most abundant water springs ${ }^{2}$ (Map 2). It provides about 5.26 million cubic meters of water annually, the water source for the ranches farm and the government farms near the palace Al Maamoura, and

2 - Development and Environment Planning Committee, Dhofar, Undated, Khairan and Springs, Dhofar, Summary of the Technical Team Report, Salalah, Sultanate of Oman 


\section{الجمعية المصرية للقر اعة و المعرفة عضو الجمعية الدولية للمعرفة ILA}

the abundance of water in this water spring led to the increase of green areas for recreation and recreation. A large garden was established in the Al Ain area, which includes a large number of trees of different shapes and types. Which encourages the prolongation of the time spent by the tourist in the area during the day only (provided that he carries with him everything related to his livelihood throughout his presence in the region of Al Ain) for lack of services on the one hand and lighting at night on the other hand in all areas exploited tourism in Dhofar, It may be appropriate to practice tourist activity under the influence of low temperatures.

\section{Photo 1: Ain Rizat}

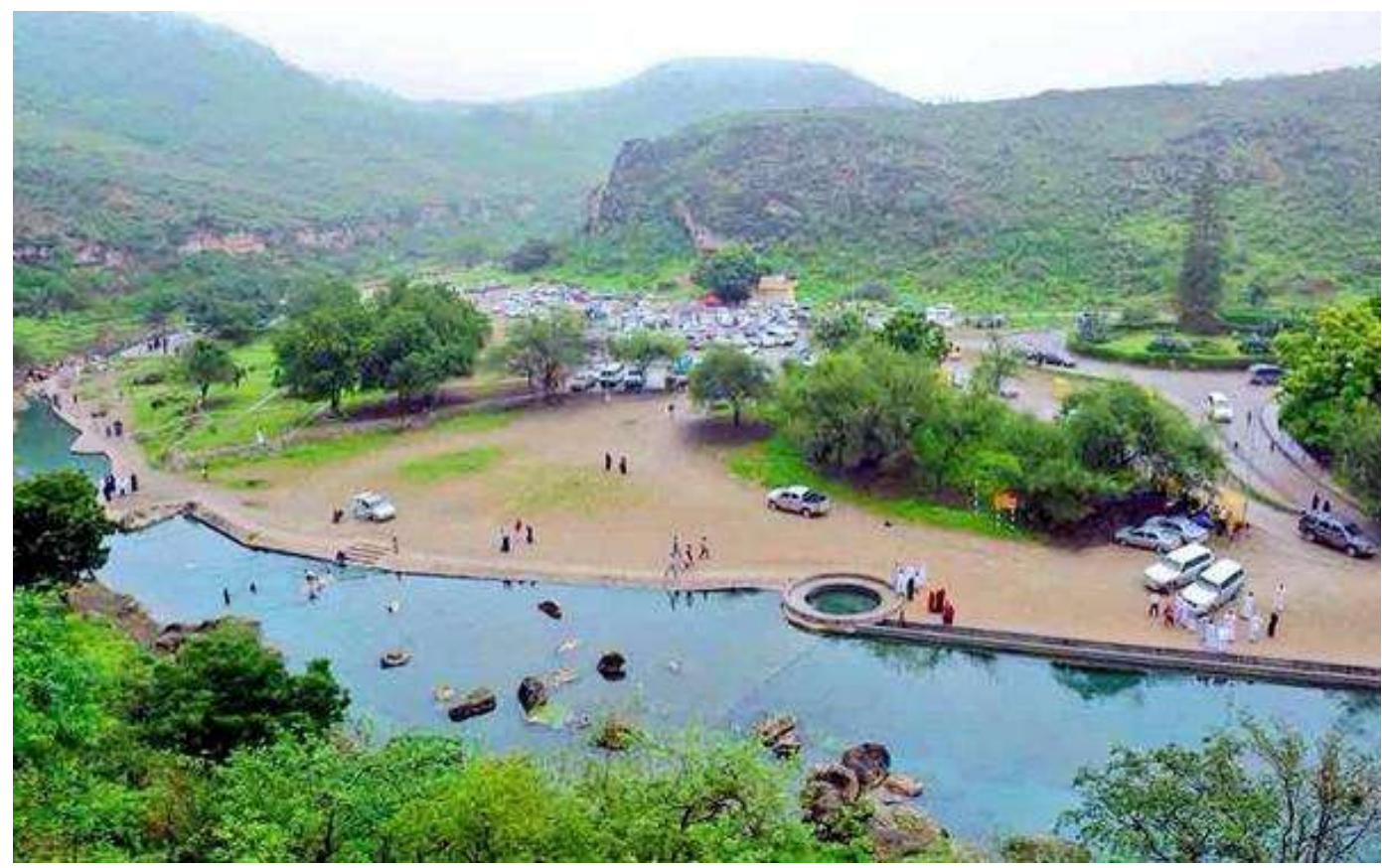

Ain $\operatorname{Rizat} r Y / \cdot V / r \cdot 1 V$

the tourist movement is seasonally attracted in the summer to the fountains of the Moghasil area to the west of Salalah city about $22 \mathrm{~km}$ to the nature of the flow of fountains in this region, where the water springs from the adjacent openings in the rocks near the beach several meters next to the cave of the coastal crane in the form of water fountains at intervals of time with the issuance of sounds and high roar searched Attention and impress

I r.Natural plants 


\section{الجمعية المصرية للقر اءة والمعرفة عضو الجمعية الدولية للمعرفة ILA}

The types and types of natural plants vary in Dhofar. However, the main species that have a global heritage since the year 2000 is the frankincense tree (Fig. 2), naturally occurring without human intervention on the edges of Dhofar. of which about 6 tons per year of frankincense, and $75 \%$ of the income of the population in the provincer

Photo 2: frankincense tree

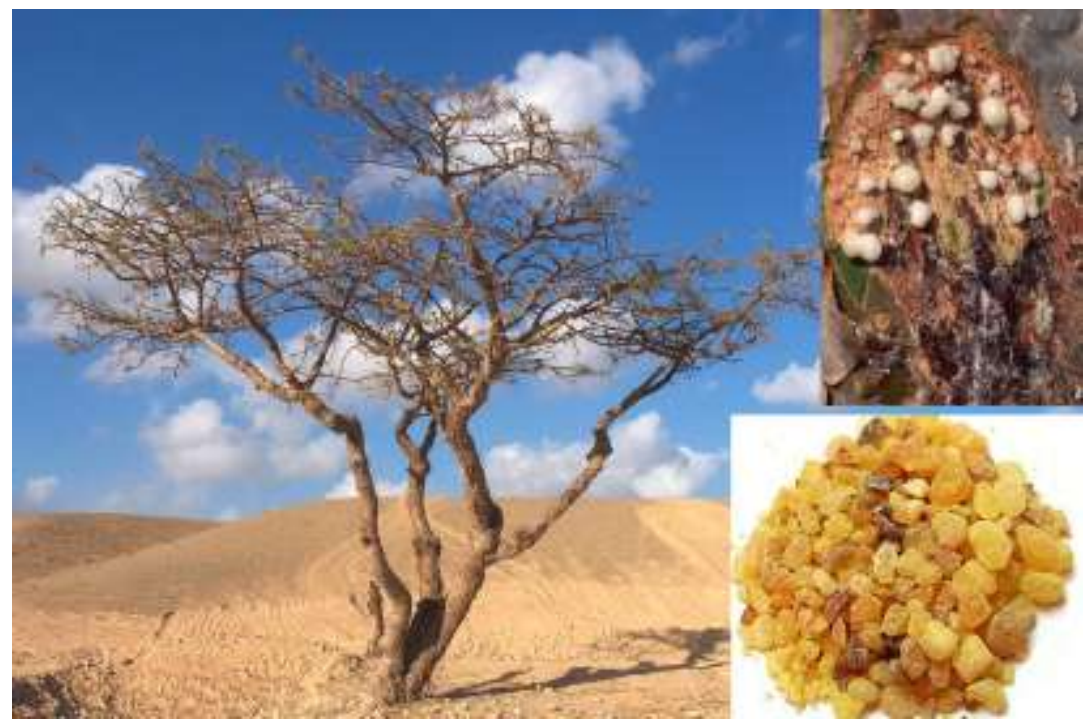

Source: FLICKR

The frankincense tree is of tourist importance and does not grow except in limited areas of the world, including the Sultanate of Oman. The province of Dhofar is characterized by the most important and finest types of frankincense (Map No. 3)، The environment in Dhofar is suitable for drought, lack of rainfall and high temperature, Thus, conditions for the growth of good frankincense trees. $^{3}$

Map No. 3: Géographical distribution of frankincense trees in Dhofar "Oman"

3 Abu El-Ela Mohamed Mahmoud (1988): Geography of Oman, Sultanate of Oman and the United Arab Emirates, Al-Falah Library for Publishing and Distribution, First Edition, Kuwait, 368 p. 


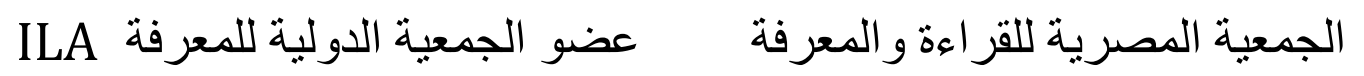

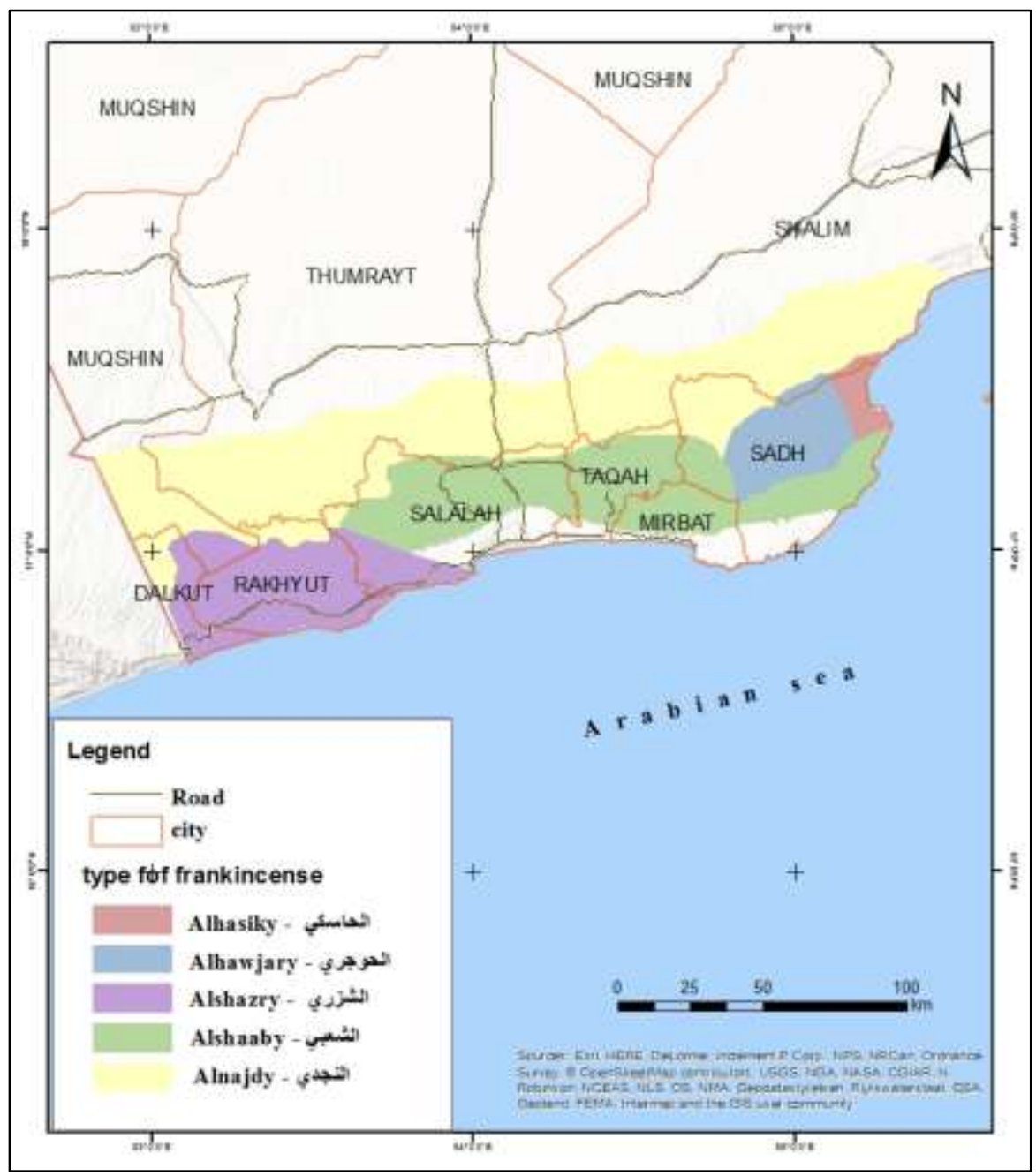




\section{ILA الجمعية المصرية للقر اءة والمعرفة عضو الجمعية الدولية للمعرفة}

\section{1.r. Natural reserve are a basis for diversifying the tourist supply of Dhofar}

The nature reserve on the Sultanate of Oman is a lesson in the tourist race from all parts of the world. We will show the most important of these important tourist destinations: ${ }^{4}$

Jabal Samhan Reserve a rare ecosystem:

Protected areas of Jabal Samhan in a series of mountains of Dhofar, the area of 4500 square kilometers, it's being a nature reserve on 28/6/1997, a series of land of limestone basal bases, (Fig. 3) An interview with the plains area and sharp bumps to the north

Photo 3: Jabal Samhan

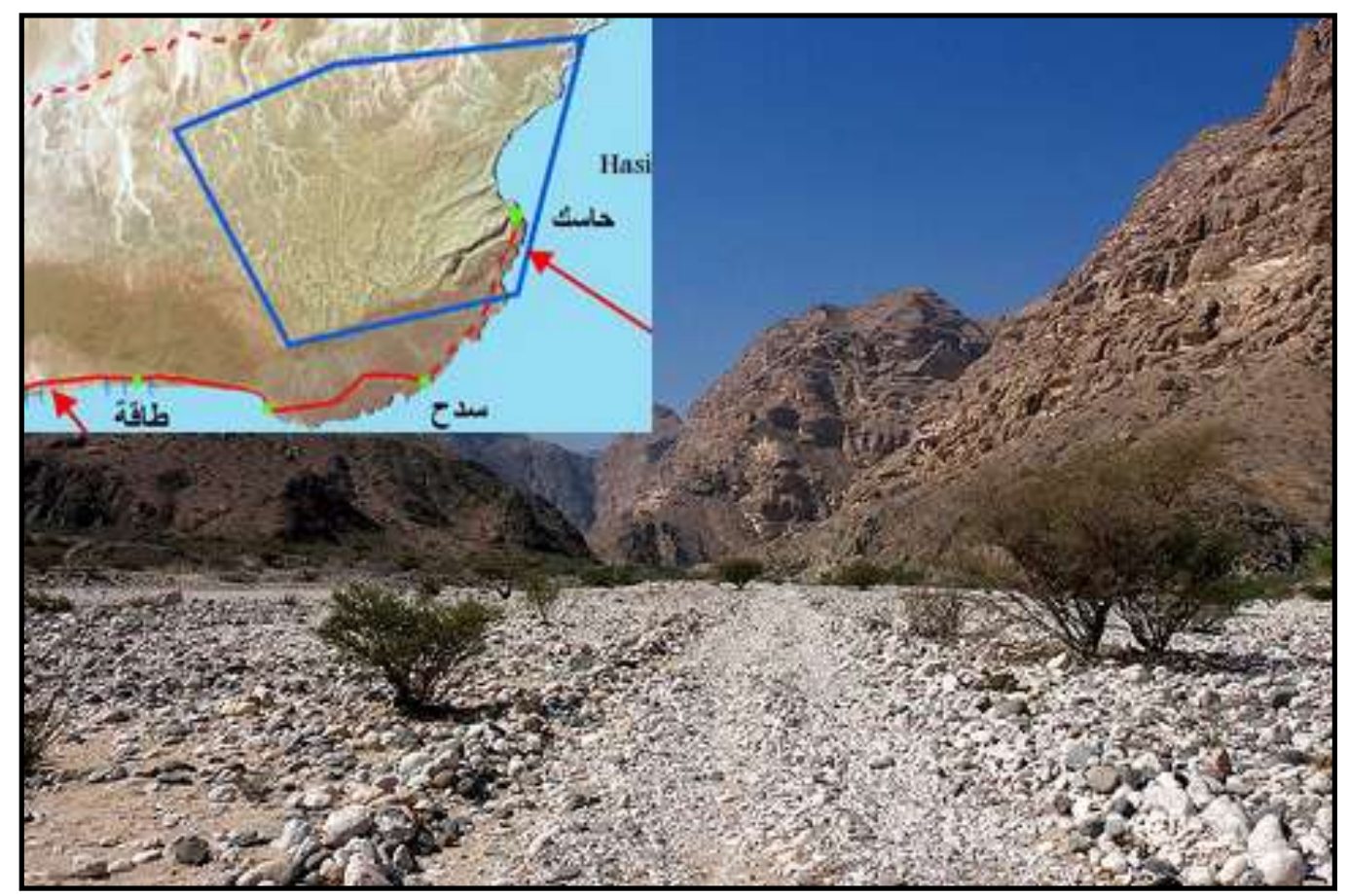

Source: FLICKR

Al Ahwar Reserves in Dhofar Coast

Located in Dhofar. Its area varies from a few hectares to more than one hundred hectares. It was declared as a nature reserve on $28 / 6 / 1997$. It is a group

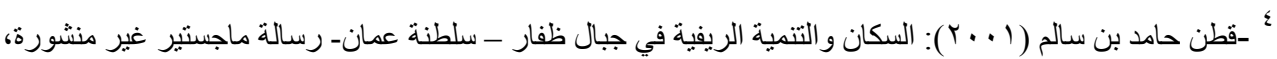

$$
\begin{aligned}
& \text { الجامعة الأردنية، عمان، ـ } 17 \text { ص. ص. }
\end{aligned}
$$




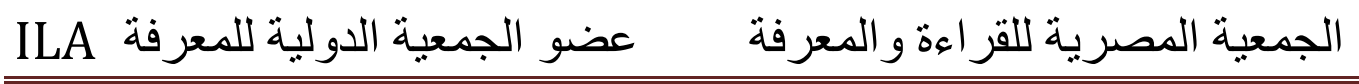

of waterworms that overlap with the land and extend along The coast of Dhofar, such as Khor al-Mogsil, Khor al-Dahariz, Khor al-Balid, Khor al-Qurum alSaghir, and the large Qurum, Khor Suli, Khor Taqa, and Khor Ruri (Picture 4). It is known for its diversity of organisms, with a huge number of birds of up to 393 species, along with sea turtles 5 .

Photo 4: Khor Rori Reserve

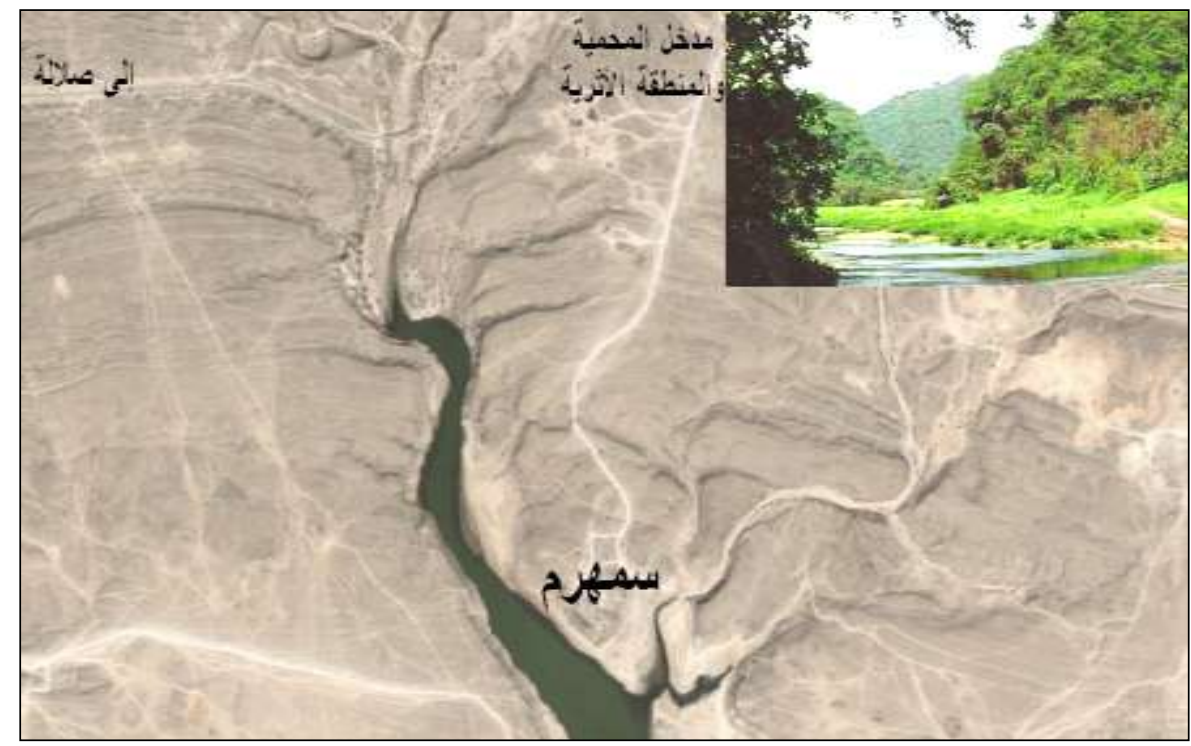

Source: FLICKR

\subsection{The coast of Dhofar is an environmental diversity and an important tourist destination}

The Dhofar has unique and attractive beaches, where the lagoons are packed with flamingos, caves and winding entrances. And the most important beaches of the province Almgassil and Rasout, which is characterized by the purity of its sand and creativity of the Creator with the beauty of its surrounding rocks and scenic nature ... There are tents such as Khor Suli and Khor al-Bled (map No. 4) and Khor Al-Daharez and Khor Athib and Khor Salalah and Khor Arqlh, which is characterized by the presence of flamingos in abundance. For those who enjoy diving and water skiing, the beaches of

${ }^{5}$ Hammad Al-Huda (1992): Agricultural Development and Fisheries in the Sultanate of Oman, Ministry of Agriculture and Fisheries, Muscat, pp. 98-101. 


\section{الجمعية المصرية للقراعة والمعرفة عضو الجمعية الدولية للمعرفة ILA}

the province are among the most important beaches in the Sultanate. These beaches and canals are easily accessible to paved roads as well as other services. ${ }^{6}$ The province also has an important coastal strip stretching more than $600 \mathrm{~km}$ on the Arabian Sea.

Map No. 4: The most important sites "khour" of Salalah

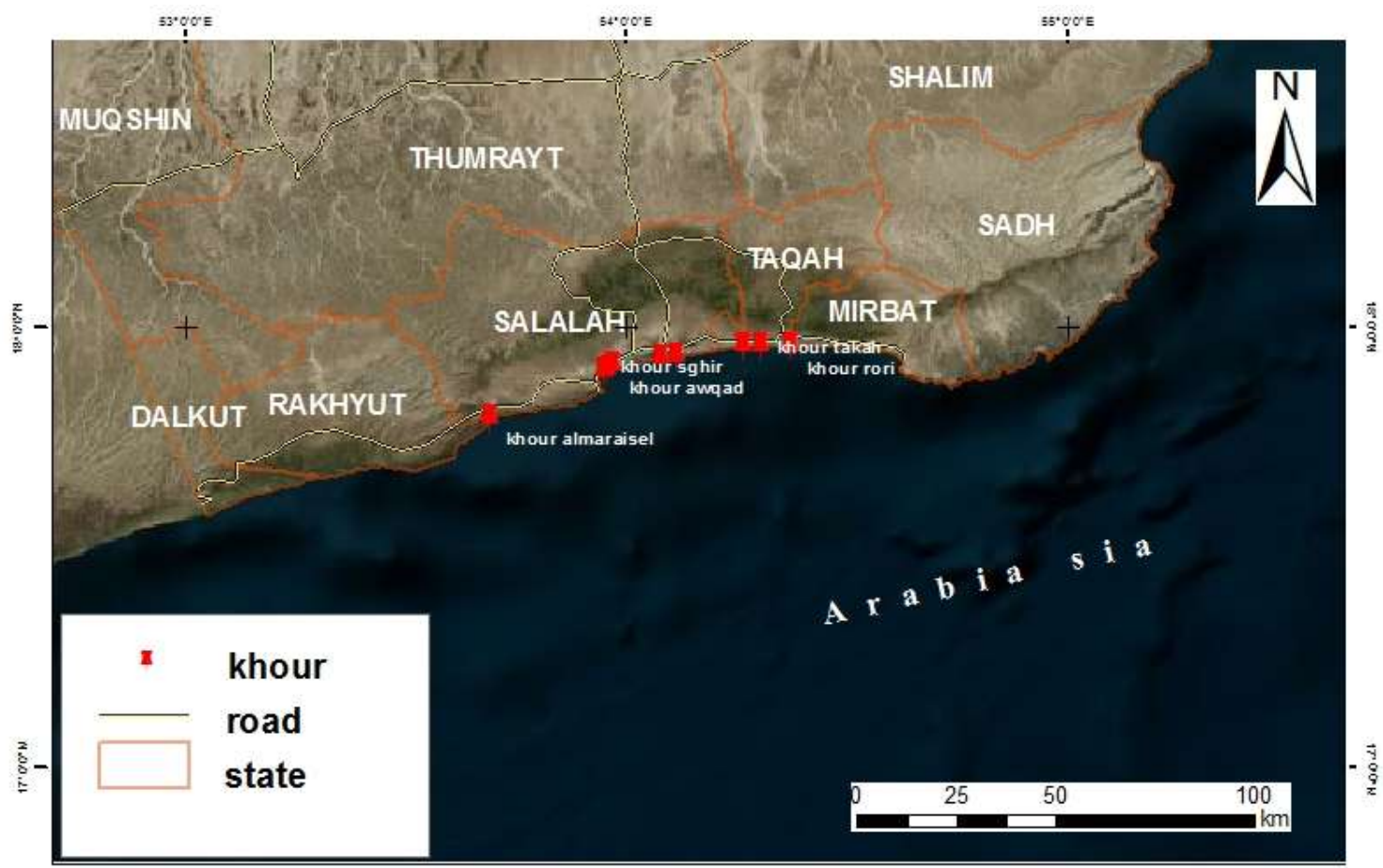

Based on the above, we find that the natural components of Dhofar play a major role in the development of tourism through the exploitation of these elements and the formation of a tourist product that attracts large numbers of tourists to recreation and recreation and exercise hobbies and enjoy the unique climate of the province, The plant and animal life, therefore, has influenced the tourism development of different types of tourist activities throughout the year.

In order to best utilize these natural qualifications, it is necessary to think about ways to sustain them and preserve them from extinction by activating ecotourism, which can play a key role in preserving this natural system,

6 6 أبو سيدو أحمد (1 ( . (Y): صلالة فردوس الخليج، منشورات وزارة الإعلام، مسقط، سلطنة

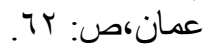




\section{الجمعية المصرية للقراءة والمعرفة عضو الجمعية الدولية للمعرفة ILA}

especially as these elements represent the most important qualifications that has Sustainable environmental tourism activity.

\section{r.Tourism Development of Dhofar Governorate:}

The tourist qualifications of Dhofar Governorate, which are characterized by nature, climate diversity, ease and diversity of customs and traditions, and easy access to tourist sites, play a crucial role in attracting a large number of tourists. The number of tourists has grown between 2018 and 2004; 2.3 Million . The number of visitors to the Salalah autumn from 21 June to 21 September 2018 (826) visitors to ensure economic, social and environmental development through the provision of infrastructure and employment opportunities for young people and the preservation of the environment. This goal will be achieved only by overcoming the various problems that stand In the face of tourism development in the province with finding appropriate solutions to them.

Eco-tourism is a process of learning, culture and education with the components of the environment, thus it is a means of introducing tourists to the environment and engaging in it. The sustainable tourism is the best exploitation of the tourist sites in terms of tourists entering in balanced numbers of tourist sites to be aware of the prior knowledge of the importance of tourist areas and deal with them, In order to prevent damage.

Sustainable tourism meets the needs of tourists, as it works to preserve tourist areas and increase employment opportunities for the local community. It works to manage all available resources, whether economic, social, aesthetic or natural, in dealing with heritage and cultural data, in addition to the need to maintain ecological balance and biodiversity.

Dhofar is characterized by a diversity of its heritage resources, which constitute a huge asset for development, especially tourism development, which requires rational and dynamic intervention in this area through an integrated development policy based on these resources without depleting them. Therefore, eco-tourism must be developed which contributes to protecting the environment and promoting tourism through Infrastructure and equipment to create tourist orbits to relieve the pressure exerted on coastal resources. In addition to natural resources, cultural tourism and heritage must also be taken to diversify the tourism product. Damage to coastal private (forest and beach) and activate the 
legal framework for the protection of the environment public and private coastal environment and the involvement of the various components of society for sustainable management of the benefit of humanity and its surroundings.

In most of the countries in the world, the Sahel is considered to be one of the most over-exploited areas for its natural and environmental benefits due to the current consumption patterns, the concentration of many economic activities, the ongoing urbanization (eg Salalah) In the field of processing, infrastructure and energy. These pressures are compounded by the growing seasonal tourism activity year after year, which is associated with the nature of the seasonal climate. Therefore, the coast is a space in which the challenges of sustainable development are particularly important given the threat to the economy and the environment of the marine environment and coastal ecosystems in general.

In general, tourism development is of great importance for achieving economic and social development in the country through a kind of homogeneity, coordination and coordination between different productive and service sectors to achieve progress in the quality of life and levels and achieve prosperity for citizens. It is not possible to achieve all this as a final goal, Various production and service sectors, including the tourism sector. Working towards the development of tourism in an integrated sense is an end in itself, while at the same time it is a stage in achieving a greater goal of achieving economic and social development in the state.

If sustainable tourism development should address the analysis of available land resources, the potential for development of agriculture, industry, fisheries, livestock and other activities, as well as urban development, this sound trend of tourism development or industrialization can not stand alone in the field; Integrated with him and supported by other productive and reconstruction activities, so that tourism development will not become the invention of projects with no roots. 


\section{r. Future prospects for tourism development}

After assessing the current reality of tourism in Dhofar Governorate, which is important, its components and types, the study of the future features of this important sector can be determined through the following:

- more tourist facilities

In response to the increase in the number of tourists during the period from 2013 to 2015, where the volume of tourism movement from 433.639 thousand tourists to 514.777 thousand tourists to the province of Dhofar, the future plans to develop a program to visit the tourist facilities, and this by building more hotels and the establishment of many tourism projects .It is expected that the number of tourists will increase significantly during the next ten years. Hence, the importance of building more tourist facilities and facilities from hotels, restaurants and restrooms. A plan has been put in place for the establishment of the Tourism project. The project has allocated 35 million riyals to establish the first phase of the project. And visitors in the fall of Salalah. ${ }^{7}$

- Tourist promotion

It included plans to increase tourism to promote tourism during the next stage through various media, and issuing brochures for monuments natural and historical attractions. The tourism promotion and marketing of activation methods for the tourism sector since the presence of the tourism potential without the ability to exploit these ingredients in attracting tourists and marketing of the tourism product, does not contribute to support the local economy, but this contribution comes as a result of success in the marketing of the product process. There is no doubt that the marketing activity in the Omani tourism sector suffers many of the problems and obstacles that limit the contribution of this sector to support the local economy

- Higher Education Specialized in Tourism

The establishment of tourism departments in the specialized colleges provides more graduates who cater to tourism sector specialists for the development of tourism. As well as hotel specialties and various tourist services.

7 - Ministry of Information website. $r \cdot 17:$ https://www.omaninfo.om/ 


\section{Conclusion}

The process of developing and developing tourism is by the inventory of sources that can be used in tourism industry and evaluated scientifically, and even find new areas that attract tourists such as tourist villages or places built especially for tourism. The calendar here is not just a theoretical guess, but a comparative calendar with the tourism products of the competition countries and their dependence on the trends and characteristics of global tourism demand, which is the basis in identifying and creating the infrastructure and national tourism through encouraging tourism investment and facilitating the work of investment companies through the reduction of taxes and customs procedures on the necessary equipment and equipment For their lives.

The study of the dynamics of the tourism and accommodation movement in Dhofar is of great importance in order to know a range of variables, analyze and interpret them. First, we must emphasize that the tourism movement is greatly affected by the abundance or lack of tourist accommodation in the governorate and the level of services provided there. In the forms of accommodation and the quality of services provided in it and the appropriate price has increased the possibility of attracting tourism and thus the large volume of tourism traffic and increased tourism income and vice versa. Hotels at different levels and hotel apartments are the main forms of tourist accommodation in Dhofar .

\section{Bibliographical references:}

- Abu El-Ela Mohamed Mahmoud (1988): Geography of Oman, Sultanate of Oman and the United Arab Emirates, Al-Falah Library for Publishing and Distribution, First Edition, Kuwait, 368 p.

- Development and Environment Planning Committee, Dhofar, Undated, Khairan and Springs, Dhofar , Summary of the Technical Team Report, Salalah, Sultanate of Oman.

- Hammad Al-Huda (1992): Agricultural Development and Fisheries in the Sultanate of Oman, Ministry of Agriculture and Fisheries, Muscat, pp. 98101. 


\section{الجمعية المصرية للقراعة والمعرفة عضو الجمعية الدولية للمعرفة ILA}

- Lew Alan \& Al (2008): World Geography of Travel and Tourism: A Regional Approach, p:33.

- Ministry of Information website. ${ }^{-1} 17$ : https://www.omaninfo.om/

• ـ أبو سيدو أحمد ( ( . ب): صلالة فردوس الخليج، منشورات وزارة الإعلام، مسقط، سلطنة عمان،

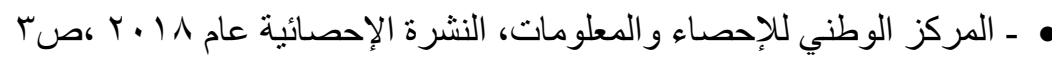

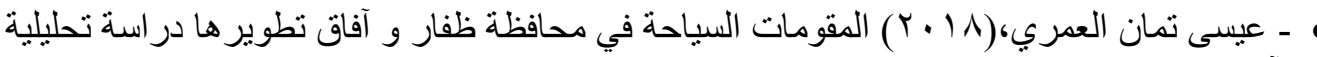

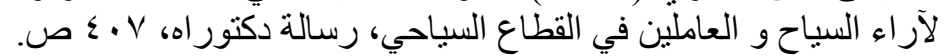

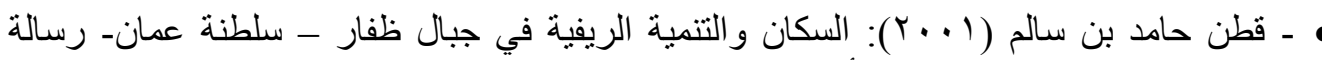

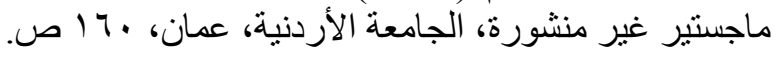

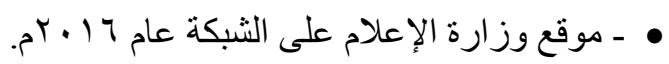

